НАУКОВИЙ ВІСНИК

Sientific mesesenger of Liviv National Lniversity of

1

$\sqrt{3}$

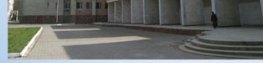

СЕРЯя: ВЕТЕРИНАРНН НАУКИ

Том 23 № 101

2021
Науковий вісник Дьвівського національного університету ветеринарної медицини та біотехнодогій імені С.3. Гжицького. Серія: Ветеринарні науки

Scientific Messenger of Lviv National University of Veterinary Medicine and Biotechnologies. Series: Veterinary sciences

UDC 619:614.31:637.5:661.41

\title{
Monitoring of compliance of quality and safety of cooked smoked sausages "Servelat" with the requirements of the national standard
}

\author{
M. S. Khimych ${ }^{1}$, K. O. Rodionova ${ }^{1}$, V. Z. Salata ${ }^{2}$, T. S. Matviishyn ${ }^{2}$, O. M. Gorobei ${ }^{1}$, Zn. B. Koreneva ${ }^{1}$ \\ ${ }^{1}$ Odessa State Agrarian University, Odessa, Ukraine \\ ${ }^{2}$ Stepan Gzhytskyi National University of Veterinary Medicine and Biotechnologies Lviv, Ukraine
}

\section{Article info}

Received 04.01.2021

Received in revised form 03.02 .2021

Accepted 04.02.2021

Odessa State Agrarian University Panteleymonyvska Str., 13, Odessa, 65012, Ukraine.

Tel.: +38-067-799-21-13

E-mail:khimichms@gmail.com

Stepan Gzhytskyi National University of Veterinary Medicine and Biotechnologies Lviv,

Pekarska Str., 50, Lviv, 79010,

Ukraine.

Tel.: +38-067-728-89-33

E-mail: salatavolod@ukr.ne
Khimych, M. S., Rodionova, K. O., Salata, V. Z., Matviishyn, T. S., Gorobei, O. M., \& Koreneva, Zn. B. (2021). Monitoring of compliance of quality and safety of cooked smoked sausages "Servelat" with the requirements of the national standard. Scientific Messenger of Lviv National University of Veterinary Medicine and Biotechnologies. Series: Veterinary sciences, 23(101), 4449. doi: $10.32718 /$ nvlvet 10108

Meat products, in particular sausages, play a significant role in the structure of retail trade among other product groups. Sausages are a traditional product of the food industry in Ukraine, and the share of cooked and smoked sausages is up to $51 \%$ of total production. Today, fierce competition encourages producers to introduce new recipes into production, which, unfortunately, has led to a sharp increase in cases of falsification of sausages. In addition, a significant number of low-capacity enterprises are involved in production, which often leads to a decrease in the sanitary quality of manufactured products. Therefore, the purpose of our study was to analyze the compliance of quality and safety indicators of cooked and smoked sausage of the highest grade of different manufacturers to DSTU 4591:2006 "Cooked smoked sausages. General specifications". The material of our research were samples of cooked smoked sausage of the highest grade "Servelat" of several domestic producers. The research was conducted on the basis of Multidisciplinary Laboratory of Veterinary Medicine (Faculty of Veterinary Medicine and Biotechnologies of Odesa State Agrarian University) and on the basis of the laboratory of Department of VeterinarySanitary Inspection (Stepan Gzhytskyi National University of Veterinary Medicine and Biotechnologies, Lviv). Sampling, organoleptic analysis of sausages and determination of microbiological parameters were performed in accordance with current regulations, determination of chemical composition - using an express analyzer FoodScan, general toxicity - express method using the infusoria Colpoda steinii. According to the results of the analysis of the labeling, it is established that the packaging of all investigated products contains the basic production and consumer information in accordance with Article 6 of the Law of Ukraine "On information for consumers about food", but on the labels of samples № 2 and 3 there is no data provided for in Article 23 of this Law - the content of unsaturated fats, sugars and salt. The study of organoleptic and microbiological parameters of sausage samples demonstrates their compliance with the requirements of the regulated DSTU 4591:2006 "Cooked smoked sausages. General specifications". The general toxicity of sausages was also not detected. The analysis of physicochemical parameters revealed non-compliance of sample № 3 with the requirements of the national standard in terms of mass content of moisture - excess by $5.72 \%$. In addition, a sufficiently high collagen content of $2.3 \pm 0.04$ was found in sausage loaves of sample № 1 .

Key words: veterinary and sanitary inspection, meat products, cooked smoked sausages, quality, safety.

\section{Моніторинг відповідності якості та безпеки ковбаси варено-копченої “Сервелат” вимогам національного стандарту}

\author{
М. С. Хімич ${ }^{1}$, К. О. Родіонова ${ }^{1}$, В. 3. Салата ${ }^{2}$, Т. С. Матвіїшин ${ }^{2}$, О. М. Горобей${ }^{1}$, Ж. Б. Коренєва \\ ${ }^{1}$ Одеський державний аграрний університет, м. Одеса, Україна
}




\section{${ }^{2}$ Львівський національний університет ветеринарної медицини та біотехнологій імені С. 3. Гэсицького, м. Львів,} Україна

М'ясні товари, зокрема ковбасні вироби, займають вагому частку у структурі роздрібного товарообороту серед іниих товарних груп. Ковбасні вироби є традичійим для України продуктом харчової промисловості, а частка варено-копчених ковбас становить до $51 \%$ загального обсягу виробництва. Сьогодні гостра конкурентна боротьба спонукає виробників впроваджувати у виробництво нові рецептури, щзо, на жаль, призвело до різкого зростання випадків фальсифікації ковбасних виробів. Окрім того, у виробниитві задіяна значна кількість малотонажних підприємств, шо часто призводить до зниження санітарної якості виготовлених виробів. Тому метою нашого дослідження було проаналізувати відповідність показників якості та безпечності ковбаси варено-копченої вищого сорту різних виробників ДСТУ 4591:2006 “Ковбаси варено-копчені. Загальні технічні умови”. Матеріалом наших досліджень були зразки ковбаси варено-копченої вищого сорту “Сервелат” кількох вітчизняних виробників. Дослідження проводили на базі багатопрофільної лабораторії факультету ветеринарної медицини Одеського державного аграрного університету та лабораторії кафедри ветеринарно-санітарного інспектування Львівського національного університету ветеринарноі медииини та біотехнологій імені С. 3. Гжичького. Відбір проб, органолептичний аналіз ковбасних виробів і визначення мікробіологічних показників проводили згідно з чинними нормативними документами, визначення показників хімічного складу - за допомогою експрес-аналізатора FoodScan, загальну токсичність - експрес-методом з використанням інфузорї Соlрода steiniі. За результатами аналізу маркування встановлено, щуо на пакуванні всіх досліджених виробів зазначено основну виробничу $і$ споживчу інформацію відповідно до ст. 6 Закону України “Про інформачію для споживачів щчодо харчових продуктів”, але на етикетках зразків № 2 і 3 відсутні дані, передбачені ст. 23 зазначеного Закону - вміст ненасичених жирів, иукрів $і$ солі. Дослідження органолептичних $i$ мікробіологічних показників зразків ковбас демонструє їх відповідність вимогам, регламентованих ДСТУ 4591:2006 “Ковбаси варено-копчені. Загальні технічні умови”. Загальної токсичності ковбас також не виявлено. Аналіз фізико-хімічних показників встановив невідповідність зразка № 3 вимогам начіонального стандарту за вмістом масової частки вологи - перевищення на 5,72 \%. Окрім того, у ковбасних батонах зразка № 1 встановлено достатньо високий вміст колагену 2,3 $\pm 0,04$.

Ключові слова: ветеринарно-санітарне інспектування, м'ясні продукти, ковбаса варено-копчена, якість, безпечність.

\section{Встуі}

В умовах ринкової економіки особливо важливим $€$ забезпечення населення конкурентноспроможними та водночас високоякісними і безпечними харчовими продуктами. М'ясні товари, зокрема ковбасні вироби, займають вагому частку у структурі роздрібного товарообороту серед інших товарних груп (Basaraba, 2017; Bogatko et al., 2017; Rodionova \& Paliy, 2018; Biletska et al., 2020; Hviazdovskyi et al., 2020; Liakhovska, 2020; Petkov, 2020).

Ковбасні вироби є традиційним для України продуктом харчової промисловості. Згідно з аналітичними даними, ковбаси споживає 90-95 \% українців, а частка варено-копчених ковбас становить до $51 \%$ (Honcharuk et al., 2019; Biletska et al., 2020; Davydova \& Zozul'kov, 2020; Paliy et al., 2020; Znachek et al., 2020).

Сьогодні м'ясопродукти виготовляють численні м'ясопереробні підприємства різної потужності. В результаті виробництво варено-копчених ковбас нараховує, крім класичного асортименту, значну кількість найменувань ковбасних виробів. 3 метою підвищення привабливості для споживача вітчизняні виробники стали приділяти все більше уваги маркуванню своєї продукції, не завжди дотримуючись регламентуючих нормативно-правових актів. Також посилення конкурентної боротьби спонукає виробників впроваджувати у виробництво нові рецептури, які забезпечують більш раціональне використання продуктів забою та різних харчових добавок, що в останні роки призвело до різкого зростання випадків асортиментної та якісної фальсифікації. Окрім того, наявність значної кількості малотонажних підприємств часто призводить до зниження санітарної якості виготовлених виробів (Kotelevych \& Larina, 2017; Paliy et al., 2018; Ofilenko, 2019; Hranovska, 2020; Khimych et al., 2020).
Тому питання належного контролю якості та безпечності ковбасних виробів є актуальним.

Мета та завдання дослідження. Враховуючи вищевикладене, метою нашого дослідження було проаналізувати показники якості та безпечності ковбас варено-копчених "Сервелат" вищого сорту різних виробників на відповідність ДСТУ 4591:2006 "Ковбаси варено-копчені. Загальні технічні умови" 3 виконанням таких завдань:

- проаналізувати відповідність маркування;

- провести аналіз органолептичних показників;

- провести аналіз основних показників хімічного складу;

- провести аналіз окремих показників безпечності (мікробіологічні показники, загальна токсичність).

\section{Матеріал і методи досліджень}

Об'єктом досліджень слугували зразки ковбаси варено-копченої вищого сорту "Сервелат" вітчизняних виробників: Зразок № 1, Зразок № 2 i Зразок № 3, відібрані шляхом контрольної закупки у торгівельній мережі міст Одеси ("Копійка", “Обжора”) та Львова (“Вопак”, “Сільпо”).

Експериментальні дослідження проводили на базі багатопрофільної лабораторії факультету ветеринарної медицини Одеського державного аграрного університету лабораторії кафедри ветеринарно-санітарного інспектування Львівського національного університету ветеринарної медицини та біотехнологій імені С. 3. Гжицького. Аналіз маркування ковбас проводили відповідно до Закону України "Про інформацію для споживачів щодо харчових продуктів" (2019); відбір зразків і сенсорну оцінку ковбас - згідно 3 ДСТУ 4823.2:2007; визначення масової частки білка, жиру, вологи, натрію хлориду, золи i колагену - за допомогою 
експрес-аналізатора FoodScan Lab (FOSS); визначення мікробіологічних показників - згідно з ДСТУ ISO 4832:2015 (наявність БГКП (коліформні бактеріі), ГОСТ 29185-91 (наявність сульфіторедукуючих клостридій у 1 г продукту), ДСТУ ISO 6888-2:2003 (наявність стафілококів у 1 г продукту), ДСТУ ISO 11290-2-2003 (наявність лістерій), ДСТУ EN 12824-2004 (наявність сальмонел у 25 г продукту); загальну токсичність - мікробіологічним експрес-методом $з$ використанням інфузорії Colpoda steinii.

\section{Результати досліджень}

На першому етапі наших досліджень провели аналіз маркування зразків ковбасних виробів (табл. 1).

\section{Таблиця 1}

Аналіз маркування ковбаси варено-копченої “Сервелат” вищого сорту

\begin{tabular}{|c|c|c|c|}
\hline \multirow{2}{*}{ Дослідний показник } & \multicolumn{3}{|c|}{ Зразки } \\
\hline & 1 & 2 & 3 \\
\hline $\begin{array}{l}\text { Документ, відповідно до } \\
\text { якого продукт вироблено }\end{array}$ & \multicolumn{3}{|c|}{ ДСТУ 4591:2006 } \\
\hline $\begin{array}{l}\text { Перелік } \\
\text { інгредієнтів }\end{array}$ & $\begin{array}{c}\text { М’ясна сировина } 100 \text { \% } \\
\text { (свинина знежилована жирна } \\
\text { або грудинка свиняча, } \\
\text { яловичина знежилована вищого } \\
\text { гатунку, свинина знежилована } \\
\text { нежирна), сіль кухонна, цукор } \\
\text { білий, перець чорний мелений, } \\
\text { горіх мускатний мелений, } \\
\text { аскорбінова кислота } \\
\text { (антиоксидант), фіксатор } \\
\text { кольору (нітрит натрію) }\end{array}$ & $\begin{array}{c}100 \text { \% (свинина жирна, свинина } \\
\text { нежирна, яловичина вищого } \\
\text { сорту), сіль кухонна харчова, } \\
\text { цукор, перець чорний мелений, } \\
\text { мускатний горіх мелений, } \\
\text { стабілізатор кольору Е } 250\end{array}$ & $\begin{array}{c}\text { м’ясна сировина } \\
\text { (свинина знежилована } \\
\text { жирна, свинина } \\
\text { знежилована нежирна, } \\
\text { яловичина знежилована } \\
\text { вищого сорту), сіль } \\
\text { кухонна, цукор, } \\
\text { прянощі (перець } \\
\text { чорний, горіх } \\
\text { мускатний), } \\
\text { стабілізатор кольору } \\
\text { нітрит натрію }\end{array}$ \\
\hline $\begin{array}{l}\text { Поживна / харчова } \\
\text { цінність продукту, } 100 \text { г }\end{array}$ & $\begin{array}{c}\text { білки 19,5 г; } \\
\text { жири 25,2 г, } 3 \text { них ненасичені } \\
\text { жири 10,3 г; } \\
\text { вуглеводи } 0,5 \text { г, } 3 \text { них цукри 0,4 } \\
\text { г; сіль 8,4 г }\end{array}$ & $\begin{array}{c}\text { білків - не менше } 15,0 \text { г; } \\
\text { жирів - не більше 45,0 г; } \\
\text { вуглеводів - } 0 \text { г. }\end{array}$ & $\begin{array}{c}\text { білки - не менше } 15,0 \text { г; } \\
\text { вуглеводи - } 0 \text { г; } \\
\text { жири - не більше 45,0 г. }\end{array}$ \\
\hline $\begin{array}{l}\text { Енергетична цінність } \\
\text { продукту, } 100 \text { г }\end{array}$ & 1272 кДж / 307 Ккал & 465 Ккал / 1945,5 кДж & $\begin{array}{c}1945,5 \text { кДж } \\
(465,0 \text { Ккал) }\end{array}$ \\
\hline $\begin{array}{l}\text { Умови зберігання і } \\
\text { термін придатності }\end{array}$ & $\begin{array}{c}\text { Умови зберігання упакованої } \\
\text { під вакуумом: за температури } \\
\text { від від } 0{ }^{\circ} \mathrm{C} \text { до } 6 \text { } \mathrm{C} \text { та за } \\
\text { відносної вологості повітря від } \\
75 \text { \% до } 78 \text { \%, за умови } \\
\text { цілісності упаковки. } \\
\text { Умови зберігання після } \\
\text { відкриття упаковки: за } \\
\text { температури від } 0{ }^{\circ} \mathrm{C} \text { до } 6 \text { C та } \\
\text { за відносної вологості повітря } \\
\text { від } 75 \text { \% до } 78 \text { \%. } \\
\text { Строк придатності та дата } \\
\text { виробництва вказана на } \\
\text { додатковій етикетці. }\end{array}$ & $\begin{array}{c}\text { за відносної вологості повітря від } \\
75 \text { \% до } 78 \text { \% та за t від від } 0{ }^{\circ} \mathrm{C} \text { до } \\
15^{\circ} \mathrm{C}-15 \text { діб; за t від від } 0{ }^{\circ} \mathrm{C} \text { до } \\
6{ }^{\circ} \mathrm{C}-1 \text { місяць; за t від від мінус } \\
7{ }^{\circ} \mathrm{C} \text { до мінус } 9{ }^{\circ} \mathrm{C} \text { - не більше ніж } \\
4 \text { місяці. } \\
\text { Ковбаси упаковані під вакуумом у } \\
\text { плівку або у модифікованому } \\
\text { газовому середовищі за t від від } \\
0 \text { } \mathrm{C} \text { до } 6{ }^{\circ} \mathrm{C} \text { цілим виробом - } 30 \text { діб; } \\
\text { сервірувальною нарізкою - } 12 \text { діб; } \\
\text { порційною нарізкою - } 20 \text { діб. } \\
\text { Дата виготовлення зазначена на } \\
\text { стікері }\end{array}$ & $\begin{array}{c}\text { за температури не вище } \\
6 \text { ॰ } \mathrm{C} \text { та відносної } \\
\text { вологості повітря від } \\
75 \text { \% до } 78 \text { \%. } \\
\text { Дата виробництва та } \\
\text { кінцева дата } \\
\text { споживання "Вжити до” } \\
\text { зазначені на стікері }\end{array}$ \\
\hline $\begin{array}{l}\text { Найменування та } \\
\text { місцезнаходження } \\
\text { виробника (потужностей } \\
\text { виробництва) }\end{array}$ & + & + & + \\
\hline Додаткові позначки & М'ясна сировина 100 \% & Без ГМО & - \\
\hline $\begin{array}{l}\text { Додаткова етикетка / } \\
\text { Стікер }\end{array}$ & $\begin{array}{c}\text { Дата виробництва ..... } \\
\text { Вжити до ...... } \\
\text { Маса нетто ..... } \\
\end{array}$ & $\begin{array}{c}\text { Дата виробництва ..... } \\
\text { Вжити до ..... } \\
\text { Вага нетто ..... } \\
\end{array}$ & $\begin{array}{c}\text { Маса нетто ...... } \\
\text { Дата виробництва ..... } \\
\text { Вжити до ..... } \\
\end{array}$ \\
\hline
\end{tabular}

Встановлено, що маркування дослідних зразків ковбасних батонів відповідає ст. 6 Закону України "Про інформацію для споживачів щодо харчових продуктів” (2019). Натомість вимогам ст. 23 зазначеного Закону відповідає лише етикетка зразка № 1, тимчасом як на етикетках зразків № 2 і 3 не вказано точного вмісту складових, а лише зазначено “білків - не менше" і “жирів - не більше”, а вміст ненасичених жирів, цукрів і солі взагалі не наведено.

Окрім того, у нас виникли й інші зауваження щодо якості та вичерпності інформації, наданої на етикетках. Так, на етикетці зразка № 1 зазначено, що енергетична цінність виробу становить 1272 кДж/ 307 Ккал, тимчасом як 1272 кДж відповідають 
304 Ккал, а крім того, згідно 3 Додатком Б ДСТУ 4591:2006 передбачено калорійність продукту в межах 400-510 ккал (1675-2136 кДж). Етикетка зразка № 3 містить недостатньо вичерпну інформацію щодо умов зберігання продукту.

Надалі ми провели аналіз якості пакування дослідних ковбас. Встановлено, що у всіх досліджених зразків термоусадкова плівка щільно прилягає до ковбасних батонах, бульйону та жирових напливів під плівкою не виявлено, шви рівні та герметичні.

На другому етапі наших досліджень провели органолептичну оцінку зразків ковбас. Встановлено, що за зовнішнім виглядом батони ковбас відповідають вимогам ДСТУ 4591:2006 - прямі, довжиною $14 \pm 1,41$ см (зразки № 1 і 3) та $32 \pm 1,1 \mathrm{~cm}$ (зразок № 2), сухі, чисті, без плям, злипів, пошкодження оболонки і напливів фаршу.
Надалі батони ковбас розрізали і визначали їхню консистенцію, колір фаршу, запах і смак, оцінюючи кожен 3 дослідних показників за п’ятибальною шкалою.

За результатами оцінки встановлено, що консистенція батонів зразків № 1 і 3 щільна, а зразка № 2 пружна. У всіх дослідних зразках фарш на розрізі рівномірно перемішаний - рожевого кольору, без сірих плям, порожнин i містить рівномірно розподілені темно- та світло-червоні шматочки м'яса розміром до 4 мм. Запах і смак зразків № 1 i 3 приємні, з вираженим ароматом копчення і прянощів, в міру солоні, а у зразка № 2 виявлено надто виражений запах i надмірний, до неприємного, присмак копчення.

Узагальнені результати органолептичної оцінки зразків подані на рисунку 1.

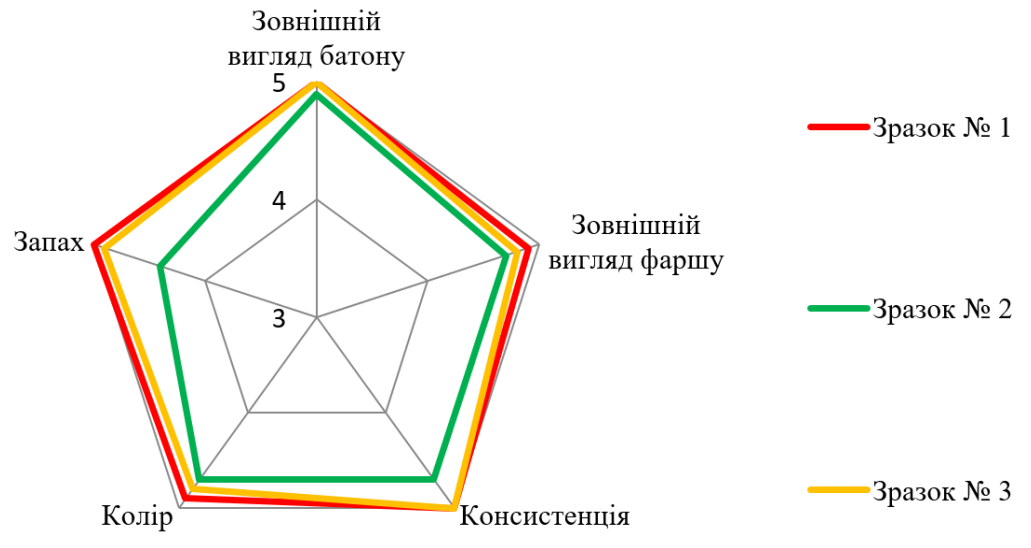

Рис. 1. Результати органолептичної оцінки ковбаси варено-копченої “Сервелат” вищого сорту

3 рисунка видно, що найвищу кількість балів $(27,7)$ набрав зразок № 1, зразок № 3 набрав 29,4 бали, а зразок № 2 набрав найменшу кількість балів - 27,6. Але, незважаючи на різну кількість отриманих балів, всі дослідні зразки за органолептичними показниками відповідали вимогам національного стандарту.

На третьому етапі наших досліджень визначали масову частку основних компонентів хімічного складу дослідних зразків ковбас (табл. 2).

\section{Таблиця 2}

Показники хімічного складу ковбаси варено-копченої “Сервелат” вищого сорту, \% $(\mathrm{M} \pm \mathrm{m}, \mathrm{n}=15)$

\begin{tabular}{lcrrr}
\hline \multirow{2}{*}{ Найменування показника } & Вимоги & \multicolumn{3}{c}{ 3разок } \\
\cline { 3 - 5 } & ДСТУ & № 1, n=5 & № 2, $\mathrm{n}=5$ & № 3, $\mathrm{n}=5$ \\
\hline Масова частка вологи, \%, не більше ніж & 45 & $46,78 \pm 0,21$ & $44,94 \pm 0,04$ & $50,72 \pm 0,01$ \\
Масова частка білка, \%, не менше ніж & 15 & $17,72 \pm 0,01$ & $22,16 \pm 0,04$ & $15,47 \pm 0,02$ \\
Масова частка жиру, \%, не більше ніж & 45 & $31,62 \pm 0,01$ & $27,75 \pm 0,04$ & $30,14 \pm 0,01$ \\
Масова частка кухонної солі, \%, не & 5 & $2,77 \pm 0,08$ & $3,25 \pm 0,13$ & $2,31 \pm 0,07$ \\
більше ніж & -- & $5,23 \pm 0,05$ & $5,61 \pm 0,04$ & $5,2 \pm 0,02$ \\
Зола, \% & -- & $2,3 \pm 0,04$ & $1,79 \pm 0,06$ & $1,18 \pm 0,22$ \\
Колаген, \% & & & \\
\hline
\end{tabular}

Встановлено, що зразки № 1 і 2 відповідають встановлення відповідності зразків вимогам ДСТУ. вимогам ДСТУ 4591:2006, а у зразку № 3 виявлено Встановлено, що вміст золи в зразках не виявив надмірну масову частку вологи - $(50,72 \pm 0,01) \%$.

Національним стандартом не встановлено вимог до таких показників, як вміст золи і колагену, тому результати щодо їх вмісту в дослідних зразках проаналізували, але не брали до уваги під час значних коливань. Натомість вміст колагену значно коливався - від $1,18 \pm 0,22 \%$ до $2,3 \pm 0,04 \%$. Враховуючи, що згідно зі стандартом та інформацією виробників щодо переліку інгрідієнтів під час виготовлення "Сервелату” використовують 
знежиловану м'ясну сировину, не зрозуміло, яким чином у зразку № 1 виявився такий значний вміст колагену.

На четвертому етапі наших досліджень визначали окремі показники безпечності зразків ковбас. За результатами оцінки мікробіологічних показників зразків № 1-3 патогенних мікроорганізмів та загальної токсичності не виявлено.

\section{Обговорення}

За результатами аналізу відповідності маркування дослідних зразків ковбаси варено-копченої “Сервелат" до чинної нормативно-правової бази виявлено, що етикетки всіх зразків містили інформацію згідно зі ст. 6, але на етикетках двох 3 трьох досліджених зразків встановлено порушення вимог ст. 23. Закону України "Про інформацію для споживачів щодо харчових продуктів”.

За результатами досліджень встановлено, що за органолептичними показниками всі досліджені зразки відповідали вимогам ДСТУ 4591:2006 “Ковбаси варено-копчені. Загальні технічні умови”, що узгоджується $з$ результатами органолептичної оцінки ковбасних виробів інших дослідників (Ievtushenko, 2018; Hranovska, 2020).

Але не можна забувати, що органолептична оцінка $\epsilon$ найпростішим методом оцінювання і не може остаточно свідчити про якість харчового продукту. Натомість показники хімічного складу дають більш об'єктивне уявлення щодо його якості та, головне, відповідності рецептурі.

Встановлена нами невідповідність хімічного складу зразка № 3 ковбаси варено-копченої “Сервелат” вищого сорту до чинних вимог національного стандарту узгоджується 3 результатами досліджень низки науковців. Адже Ушаков Ф. О. (2017), Свтушенко М. О. (2018), Котелевич В. А. (2020) та Хімич М. С. зі співавторами (2020) також виявляли порушення відповідності рецептури ковбасних виробів регламентованим вимогам і випадки їх фальсифікації (Ushakov, 2017; Ievtushenko, 2018; Kotelevych \& Larina, 2020; Khimych et al., 2020).

Щодо показників безпечності, то згідно з отриманими нами результатами, всі досліджені зразки визнано безпечними за мікробіологічними показниками та нетоксичними. Подібних висновків щодо відповідності ковбас до вимог нормативних документів дійшли Богатко Н. М. зі співавторами (2017) і Гвяздовський Р. М. (2020). Водночас окремі дослідники отримали відмінні результати. Зокрема, проведений Кіт А. А. зі співавторами (2019) моніторинг мікробіологічних показників м'ясопродуктів, встановив порушення дотримання норм державних стандартів за вмістом БГКП, результати досліджень Котелевич В. А. (2017) свідчать про невідповідність ковбас, що реалізуються, вимогам за вмістом МАФАнМ і БГКП, Офіленко Н. О. (2020) виявляла в зразках ковбас перевищення кількості МАФАнМ, гриби і дріжджі, а комплексні дослідження безпечності ковбасних виробів, проведені Ушаковим Ф.О. (2017), свідчать про невідповідність ковбасних виробів вимогам ДСТУ за такими показниками, як КМАФАнМ, вміст БГКП та сальмонел, а також виявляють токсичні властивості.

Таким чином, аналізуючи результати проведених нами та іншими науковцями досліджень, ми вважаємо, що проблема відповідності показників якості та безпечності ковбас вимогам національних стандартів потребує постійного моніторингу.

\section{Висновки}

1. За результатами досліджень встановлено, що маркування досліджених зразків батонів ковбаси варено-копченої “Сервелат” вищого сорту містить основну виробничу і споживчу інформацію згідно 3 п.1 ст. 6 Закону України "Про інформацію для споживачів щодо харчових продуктів” (2019). Однак зразки № 2 i 3 не містять інформації щодо вмісту ненасичених жирів, цукрів і солі, що порушує вимоги ст. 23 зазначеного закону.

2. За результатами дослідження хімічного складу встановлено, що у зразку № 3 масова частка вологи становила $50,72 \pm 0,01 \%$, що перевищує регламентований державним стандартом вміст на $5,72 \%$.

3. За результатами досліджень встановлено, що всі зразки за органолептичними і мікробіологічними показниками відповідали вимогам, встановленим ДСТУ 4591:2006 “Ковбаси варено-копчені. Загальні технічні умови” та не виявляли загальної токсичності.

Відомості про конфлікт інтересів. Автори стверджують про відсутність конфлікту інтересів щодо їх вкладу та результатів досліджень.

\section{References}

Basaraba, L. L. (2017). Identyfikatsiia syrokopchenykh kovbas. Materialy IV mizhnarodnoi naukovoi konferentsii studentskoi ta uchnivskoi molodi "Stan ta perspektyvy vyrobnytstva, pererobky i vykorystannia produktsii tvarynnytstva" (26-27 zhovtnia 2017, Kamianets Podilskyi), 71-72. URL: http://188.190.33.56:7980/jspui/handle/123456789/33 36 (in Ukrainian).

Biletska, Y., Perepelytsya, A., \& Bilovska, O. (2020). Substantiation of the use of the enriched flour made from legumes in the production of sausages. Technology audit and production reserves, 3(53), 3941. doi: 10.15587/2706-5448.2020.201101.

Bogatko, N., Bogatko, L., Salata, V., Semaniuk, V., Serdioucov, J., \& Schyrevuch, G. (2017). Veterinarysanitary control of safety and quality of meat products. Scientific Messenger of LNU of Veterinary Medicine and Biotechnologies. Series: Veterinary Sciences, 19(73), 7-10. doi: 10.15421/nvlvet7302.

Davydova, O. B., \& Zozulkov, O. V. (2020). Suchasnyi stan rynku kovbasnykh vyrobiv Ukrainy: kliuchovi tendentsii ta draivery rozvytku. Aktualni problemy ekonomiky ta upravlinnia, 1-11. 
URL: http://umj.metrology.kharkov.ua/index.php/241 0-4973/article/view/216900 (in Ukrainian).

Dolova, Je. Z., \& Madonova, S. V. (2018). Issledovanie kachestva kolbas i kolbasnyh izdelij na sootvetstvie fiziko-himicheskih pokazatelej s pomoshh'ju analizatora FOODSCAN. Molodezh' i nauka, 8, 38-38 (in Russian).

Honcharuk, O. V., Semenova, T. V., \& Tytarenko, T. I. (2019). Obhruntuvannia asortymentnoi politychy pidpryiemstva kharchovoi promyslovosti. Biznesnavihator, 6(55), 64-68 (in Ukrainian).

Hranovska, D. (2020). Orhanoleptychni, fizyko-khimichni pokaznyky vareno-kopchenykh kovbas. Pryrodnychi ta humanitarni nauky. Aktualni pytannia: materialy III Mizhnarodnoi studentskoi naukovo-tekhnichnoi konferentsii, 23-24 kvitnia 2020 r., m. Ternopil, 4950. URL: http://elartu.tntu.edu.ua/bitstream/lib/32017/ 2/PGNAP 2020 Granovskaya DOrganoleptic physical 49-50.pdf (in Ukrainian).

Hviazdovskyi, R. M., Bukalova, N. V., \& Utechenko, M. V. (2020). Bezpechnist ta yakist produktiv tvarynnoho pokhodzhennia. Aktualni problemy veterynarnoi medytsyny: materialy mizhnar. naukovo-praktychnoi konferentsii studentiv, 15 kvitnia 2020 r., Bila Tserkva. 10-12. URL: http://rep.btsau.edu.ua/handle/BNAU/5137 (in Ukrainian).

Ievtushenko, M. O. (2018). Porivnialnyi analiz yakosti kovbasnykh vyrobiv torhivelnykh marok "Khmelnytski delikatesy" ta "Iatran". Aktualni problemy veterynarnoi medytsyny: materialy mizhnarodnoi naukovopraktychnoi konferentsii mahistrantiv, 22 lystopada 2018 r., Bila Tserkva, 21-22. URL: https://science.btsau.edu.ua/sites/default/files/tezy/tezy_ vet magistri 2018.pdf\#page $=21$ (in Ukrainian).

Khimych, M. S., Salata, V. Z., Piven, O. T., Salata, R. V., Koreneva, Zh. B., \& Naidich, O. V. (2020). Veterynarno-sanitarna otsinka kovbasy varenoi vyshchoho sortu "Likarska". Naukovyi visnyk LNUVMBT imeni S.Z. Gzhytskoho, 22(98), 36-41. doi: 10.32718/nvlvet9806 (in Ukrainian).

Kit, A. A., Mikhailiutenko, S. M., Kruchynenko, O. V., Yevstafieva, V. O., \& Melnychuk, V. V. (2019). Mikrobiolohichni pokaznyky miasoprduktiv ta miasa pid chas yarmarkovykh zakhodiv u m. Kyievi. Visnyk Poltavskoi derzhavnoi ahrarnoi akademii, 2, 148-153. doi: 10.31210/visnyk2019.02.19 (in Ukrainian).

Kotelevych, V. A. (2017). Veterynarno-sanitarna otsinka yakosti ta bezpeky kharchovykh produktiv u
Zhytomyrskomu rehioni. Naukovyi visnyk LNUVMBT imeni S.Z. Gzhytskoho, 19(78), 58-61. doi: 10.32718/nvlvet8804 (in Ukrainian).

Kotelevych, V., \& Larina, K. (2020). Veterynarnosanitarna otsinka kovbasnykh vyrobiv u misti Zhytomyr za pokaznykamy yakosti ta bezpechnosti. Naukovyi visnyk LNUVMBT imeni S.Z. Gzhytskoho, 22(97), 112-117. doi: 10.32718/nvlvet9718 (in Ukrainian).

Liakhovska, O. V. (2020). Osnovni tendentsii zovnishnoi torhivli Ukrainy miasom ta miasnymy produktamy. Ahrosvit, 4, 70-75. doi: 10.32702/2306-6792.2020.4.70 (in Ukrainian).

Ofilenko, N. O. (2019). Otsinka yakosti i bezpechnosti kovbas vitchyznianoho vyrobnytstva. Merezhevyy̆ biznes: stanovlennia, problemy, innovatsiii: materialy IKh Mizhnarodnoi naukovo-praktychnoi internetkonferentsii, 18-19 kvitnia 2019 r., m. Poltava, 254257 (in Ukrainian).

Paliy, A. P., Rodionova, K. O., Braginec, M. V., Paliy, A. P., \& Nalivayko, L. I. (2018). Sanitary-hygienic evaluation of meat processing enterprises productions and their sanation. Ukrainian Journal of Ecology, 8(2), 81-88. doi: 10.15421/2018_313.

Paliy, A. P., Stegniy, B. T., Palii, A. P., Rodionova, K. O., Bogatko, N. M., Vashchyk, Ye. V., Sakhniuk, N. I., Ovcharenko, H. V., Dudus, T. V., Ihnatieva, T. M., \& Kovalenko, L. V. (2020). Microstructural analysis of sausage quality. Ukrainian Journal of Ecology, 10(2), 404-409. doi: 10.15421/2020 115.

Petkov, O. I. (2020). Ohliad rynku miasa ta miasnoi produktsii v Ukraini. Prychornomorski ekonomichni studii, 54, 131-136 (in Ukrainian).

Rodionova, K. O., \& Paliy, A. P. (2018). Influence of modern vacuum packaging on quality and safety of sausage products. Journal for Veterinary Medicine, Biotechnology and Biosafety, 4(1), 18-23. URL: http://nbuv.gov.ua/UJRN/jvmbb 2018416.

Ushakov, F. O. (2017). Kontrol bezpechnosti ta yakosti kovbasnykh vyrobiv: Avtoref. dys.na zdobuttia nauk. stupenia kand. vet. nauk. Kyiv (in Ukrainian).

Znachek, R. R., Sokoliuk, K. Iu., \& Muntian, I. V. (2020). Doslidzhennia nomenklatury ta asortymentu pidpryiemstva PRAT "Bezliudivskyi miasokombinat". Ekonomichnyi prostir, 156, 136-139. URL: http://prostir.pdaba.dp.ua/index.php/journal/article/vie w/551 (in Ukrainian). 